\title{
Pathways to Adult Civic Engagement: Benefits of Reflection and Dialogue across Difference in Higher Education Service-Learning Programs
}

\author{
Dan Richard \\ University of North Florida \\ Julie A. Hatcher \\ Indiana University-Purdue University Indianapolis
}

\author{
Cheryl Keen \\ Walden University \\ Heather A. Pease \\ Loyola University Chicago
}

\begin{abstract}
The current study explores the relationship between participation in college service-learning (SL) experiences, in both academic courses and co-curricular programs, and post-college civic engagement. Using data from a purposeful sample of 1,066 alumni from 30 campuses who participated in the 20th Anniversary Bonner Scholars Study, we explored the extent to which SL experiences during the college years were related to civic outcomes post-graduation, particularly in terms of civic-minded orientations, volunteering, and civic action. When evaluating various attributes of SL programs (e.g., curricular, co-curricular programming, types of reflection, dialogue across difference, interactions with others), two components were particularly salient. Dialogue with others across difference was the strongest predictor of cultivating civic outcomes after college. In addition, both structured and informal reflection independently contributed to civic outcomes (i.e., civic-mindedness, voluntary action, civic action). The results suggested the Pathways to Adult Civic Engagement (PACE) model, which can be used to examine SL programming in higher education and to guide future research to understand how variations in SL program attributes influence civic outcomes years after graduation.
\end{abstract}

The well-being of American democracy is dependent upon the active participation of its citizens and professionals in both political and community life. This voluntary impulse for engagement is shaped, in part, by traditions learned in families, clubs, religious organizations, and schools (Daloz, Keen, Keen, \& Parks, 1996; Wilson, 2000). Each of these social organizations is vital to cultivating civic commitments (Kim, Flanagan, \& Pykett, 2015). Higher education has a unique responsibility to prepare graduates with the necessary disciplinary knowledge for their careers as well as with the skills and dispositions to be active citizens through both their personal and professional lives (Sullivan $\&$ Rosen, 2008). The National Task Force on Civic Learning and Democratic Engagement (2012) and the Association of American Colleges \& Universities (Reich, 2014) recently reiterated to institutions of higher education that their mission should focus on civic engagement.

Research suggests that the college years are indeed a crucial period in the development of civic identity and engagement (Colby, Ehrlich, Beaumont, \& Stephens, 2003; Kneflekamp, 2008; Mitchell, Richard, Battistoni, Rost-Banik, Netz, $\&$ Zakoske, 2015). Civic outcomes for college stu- dents include a wide and complex range of dimensions, including civic knowledge, skills, dispositions, and behaviors related to civic identity, sense of social responsibility, and intentions to participate in politics as well as community engagement and voluntary action (Beaumont, 2012; Hatcher, 2011; Hatcher, Bringle, \& Hahn, 2016). Understanding the conditions under which higher education institutions are best able to support civic outcomes among graduates would enrich student learning, help college administrators enact coordinated and impactful academic and co-curricular servicelearning (SL) programs, and support the engagement of alumni in the public sphere.

SL, defined broadly as a course-based activity or as a co-curricular program (Jacoby, 2015), is on the rise in American higher education. Concomitantly, research on SL is increasingly prevalent. There have been a number of critiques regarding the quality of SL research in higher education (Butin, 2013; Finley, 2011; Giles \& Eyler, 2013). The research on SL often is focused on one course or one program and rarely uses multi-campus sampling strategies. Oftentimes, the research fails to identify clearly the various dimensions of the SL course design (Finley, 2011), thus attributing the outcomes to SL rather 
than to the specific characteristics of, or variations within, the SL experience itself (Giles \& Eyler, 2013). The quality of the SL experience is rarely associated with the variations in student outcomes (Hatcher, Bringle, \& Muthiah, 2004). Additionally, the majority of research on SL in higher education is focused on the short-term impact of the academic or co-curricular SL experiences on student outcomes (Conway, Amel, \& Gerwien, 2009; Yorio \& Ye, 2012), using end-of-course assessments or program evaluation strategies. Research is also limited on alumni who have completed participation in college-level SL programs and who may now be involved in their communities post-graduation (Mitchell, Battistoni, Keene, \& Reiff, 2013). Another limitation is that empirical studies on SL programs, regardless of methodological approach, often lack a theoretical or conceptual model, thus limiting the ability to evaluate the theory or conceptual model under various contexts and conditions (Hatcher et al., 2016, Steinberg, Bringle, \& McGuire, 2013).

In the current study, we used data from a large, multi-campus, formative program-wide evaluation to address some of these critiques in research on SL. Based on our analysis and interpretation of the data derived from a large, multi-institutional survey and informed by the literature, a general model emerged that can be evaluated and used to improve the design of SL programs. We explored how experiences within SL programs (i.e., reflection activities, informal interactions with mentors and peers, curricular components, co-curricular experiences, community interactions) relate to post-graduate civic outcomes (i.e., civic-mindedness, voluntary action, civic action). The conceptual model is a framework for researchers and practitioners to evaluate the relationships among key elements of SL programs and civic outcomes after graduation. First, we will describe some of the theoretical literature and previous research that informed the development of the model. Second, we will describe the model, the methods, and the results used to generate and test the model. Third, we will explore the implications and limitations of this work.

\section{Service Learning Program Features}

\section{Curricular SL Courses}

High quality SL experiences, both course-based and co-curricular, have several attributes based on principles of good practice (Council for the Advancement of Standards in Higher Education, 2015; Hahn \& Hatcher, 2015; Jacoby, 2015; National Youth Leadership Council, 2008). These at- tributes have important implications for generating civic outcomes (Stokamer \& Clayton, 2016). Research on credit-bearing SL has demonstrated its value for supporting academic learning (Conway et al., 2009; Warren, 2012), critical thinking (Conway et al.), and deep learning (Hahn \& Hatcher, 2015). Academic SL in the senior year is related to political and social involvement (Kilgo, Pasquesi, Sheets, \& Pascarella, 2014). Curricular SL provides opportunities for structured reflection, oftentimes in the form of assignments, and structured reflection has been found to deepen the meaning of the service experience and increase the reported quality of the learning experience (Ash \& Clayton, 2004; Hatcher et al., 2004; Mabry, 1998; Sturgill \& Motley, 2014).

\section{Co-curricular Programs and Experiences}

Less evidence exists on the impact of cocurricular SL programs. In a large-scale study across 38 campuses, Finley and McNair (2013) found that increased involvement in SL programs correlated with self-reported deep learning, practical competence, personal and social development, and general education outcomes. Finley and McNair's data, however, did not specify whether the SL experiences occurred in the curricular or co-curricular settings. Instead, researchers asked whether SL was happening on campus and whether students were engaged. SL experiences and engagement with racial/cultural diversity during college were associated with adult volunteerism 13 years later (Bowman, Brandenberger, Lapsley, Hill, \& Quaranto, 2010). Bowman, Park, and Denson (2014) found that participation in ethnic group organizations on campus, which often involves service, was positively associated with civic engagement 6 years later. Vogelgesang and Astin (2000), using data from more than 22,000 students, found that students participating in service only (not connected to a course but assuming some informal reflection was involved) showed learning gains in civic outcomes similar to those who had course-based SL when compared with students who did not participate in service at all. However, while those who volunteer during college have been more likely to continue to do so after they graduate compared to those who did not, Vogelsang and Astin (2005) found the rate of volunteering diminished 6 years after graduation.

\section{Reflection}

Reflection is an essential part of SL (Hatcher et al., 2004, Jacoby, 2015). Reflection is characterized as the hyphen between "service" and "learning" and noted as what distinguishes SL from volunteer- 
ism or community service (Giles \& Eyler, 2004). Reflection fosters students' ability to make meaning from experience (Bringle \& Hatcher, 1999; Eyler \& Giles, 1999), increases critical thinking (Ash \& Clayton, 2004), and supports the development of civic outcomes, including a social justice orientation (Mitchell, 2014). Fenzel and Peyrot (2005) and Vogelgesang and Astin (2000) found that reflection in SL programs, as opposed to community service without reflection, led to more community responsibility and personal political involvement among alumni. Reflection within SL has been found to contribute to moral reasoning (Boss, 1994) and changes in beliefs about one's own impact on society (Astin \& Sax, 1998), including self-efficacy and commitment to activism (Astin, Vogelgesang, Ikeda, \& Lee, 2000). Reflection is instrumental in adult identity development (Jones \& Abes, 2004; Mezirow, 2000; Mitchell et al., 2015) and in being attentive to the needs of others (Jones \& Hill, 2003; Daloz et al., 1996). Additionally, reflection is an essential component to professional practice for it can deepen insight and generate new and improved action (Brookfield, 1995; Schön 1987).

\section{Dialogue across Difference}

Another important attribute of SL courses is dialogue across perceived difference (Keen \& Hall, 2009). Dialogue across difference might happen informally at service sites, in conversations with peers while traveling to and from a service site, or in structured reflection in a class or co-curricular program activity (Keen \& Hall, 2009). When faced with racial, class, ability, or gender diversity, interactions with people who have different backgrounds and experiences can provide the cognitive dissonance necessary for intellectual and personal development (Bowman, 2011; Bowman \& Brandenberger, 2012; Diaz \& Perrault, 2010; Gurin, Dey, Hurtado, \& Gurin, 2002; Hudson \& Hunter, 2014). Dialogue across difference provides opportunities for students to experience diversity and develop a pattern of empathy for others, and this can lead to action on behalf of others. Niehaus and Rivera's (2015) analysis of a multi-campus survey of students who participated in alternative spring break trips, which are typically SL oriented programs, found that the trips provided a setting that facilitated informal interactions with diverse others. Holsapple (2012) identified interactions across difference as one of five main outcomes related to openness to diversity outcomes and reported across 55 studies of credit-bearing SL courses. Morton and Bergbauer (2015), in a description of SL programs that target long-term impact, highlighted the importance that dialogue across difference has on student learning and civic engagement. They noted, students learn "... that the personal growth they experience by participating in difficult conversations and working in complex, diverse environments can increase their desire and willingness to participate in communal and public life" (p. 28).

Dialogue across difference, when well-planned, produces important civic outcomes. Jones, Robbins, and LePeau (2011) found that students participating in short-term immersion programs including co-curricular SL deepened their understanding of social issues through sustained interaction with community members facing poverty and homelessness. However, the benefits of dialogue across difference may not always be fully realized. Research has pointed to the need for facilitators of SL programs to be careful in assuming whether or not participating students have experienced the poverty, illiteracy, or racism that the students are doing service to ameliorate. Assuming a dimension of difference may prompt students who identify with targeted social categories to experience feelings of the other, particularly students of color or those who are aware of class differences between themselves and their college peers (Mitchell et al., 2012; Seider, 2013; Seider \& Hillman, 2011).

\section{Civic Outcomes}

The goal of SL programs is to affect student outcomes. In a comprehensive review of research on civic outcomes, Hemer and Reason (2016) concluded that civic outcomes for college students are multifaceted, being classified into categories such as civic knowledge, civic skills, civic attitudes and values, and civic behaviors and participation. Together, these four dimensions of civic outcomes contribute to the formation of civic identity. This complexity in defining civic outcomes is evident in the other literature reviews (Finley, 2011) as well as rubrics designed to evaluate civic engagement (American Association of Colleges \& Universities, 2009) and civic knowledge (Civic Rubrics for Knowledge and Values, 2016). For the purposes of the current study, civic outcomes included both civic-mindedness and civic action.

Civic-mindedness, for the purposes of this study, is "a way of thinking about, and paying attention to, the public good and the well-being of society" (Checkoway, 2014, p. 77) and is defined as "a person's inclination or disposition to be knowledgeable of and involved in the community, and to have a commitment to act upon a sense of responsibility as a member of that community" (Steinberg, Hatcher, \& Bringle, 2011, p. 429). Civic- 
mindedness includes knowledge (e.g., technical knowledge within the discipline, knowledge of contemporary social issues), skills (e.g., listening, consensus building, working with diverse others), dispositions (e.g., valuing community engagement, being a social trustee of knowledge), and behavioral intentions to be involved in political and voluntary action (Steinberg et al.). In terms of life after college, civic-mindedness also includes the added domains of how one thinks about their work as a vocation and the public purposes of their profession (Hatcher, 2008). Civic-minded professionals have the public interest at the forefront of their professional work and a sense of civic responsibility to conduct their work to advance the social good (Dzur, 2004; Sullivan, 2005).

Civic action among adults focuses on a range of behaviors (as opposed to behavioral intentions and dispositions) from volunteering to voting to leading boycott campaigns. Finlay, Flanagan, and WrayLake (2011), for example, using indicators of civic action such as volunteering, civic organizational involvement, and voting, found that individuals with a college education, compared to those without a college education, sustained levels of civic involvement gained during the AmeriCorps program. Rockenbach, Hudson, and Tuchmayer (2014) found that entering college students who volunteered or did community service the year before entering college still found service to be important 6 years later. In addition, cohort-based service-scholarship programs are an effective means to support the development of civic action (Mitchell et al., 2014).

\section{Research Question}

In the current study, we explored three central aspects of college SL programs: (a) curricular and co-curricular experiences; (b) formal and informal reflection with others; and (c) dialogue across difference. We expected that variations in these elements would support the development of civic outcomes, specifically, civic-minded orientations, volunteering, and civic action. We suggest a model to address the interactions among these elements. The data provided by the Bonner Alumni Study provided a unique opportunity to ask the research question: What is the relationship among SL program experiences and the relative impact of these elements, in the context of the others, on civic outcomes post-graduation?

\section{Method}

\section{Context and Setting}

In 2010, as part of the 20th anniversary celebration of the Bonner Scholar Program (BSP), the Corella and Bertram F. Bonner Foundation (Bonner Foundation) funded a comprehensive, formative, program-wide evaluation to understand a variety of outcomes of the BSP as self-reported by alumni participants. Two members of the research team developed an online questionnaire and BSP alumni from 34 institutions of higher learning were invited to participate in the study. By design, BSP goals across colleges and universities are remarkably similar. Campus program leaders attend training sessions and receive resource materials designed to reach a set of common learning outcomes. However, campus programs have unique elements, due in part to implementation of the BSP in a variety of institutional contexts and across a number of years, which results in variation across individual student experiences. All BSPs intentionally recruit traditionally-aged college students with financial need, most of whom are Pell Grant eligible, who show an interest in and commitment to community service and engagement.

One BSP goal is to enable students to develop a sense of meaning and purpose that extends into the students' personal, professional, and civic lives. Each campus program typically involves $40-80$ students in a weekly minimum of 10 hours of community service, training, retreats, and reflection over 4 years. Participants in the first decade of the program did not have many opportunities for curricular SL, but BSP participants in the second decade of the program may have taken a variety of SL courses based on availability at their respective campuses. The majority of BSP students serve at three or more service sites over the course of their college career, and many return to the same service site over multiple semesters to develop a greater understanding of community issues within the context of that local service site. By the third and fourth years in the program, BSP students typically take on expanded leadership roles and responsibilities both on campus and in their communities. By the fourth year, BSP students develop a capstonelevel project that integrates their academic pursuits and career interests with the 1640 hours of service and program activities (Bonner Network, 2015). The service-based scholarship program uses best practices in co-curricular student development programs (Butin, 2013; Hoy \& Johnson, 2013) and aligns with other models of college student development and best practices of higher education (As- 
tin et al., 2000; Baxter-Magolda, 2000; Blaich, Pascarella, Wolniak, \& Cruce, 2004; Keeling, 2004; Kuh, Kinzie, Schuh, \& Whitt, 2005).

\section{Sample}

The Bonner Foundation retrieved addresses for $75 \%$ of the total alumni pool from 30 campuses $(N$ $=3,304)$ and sent 2,141 emails for whom email addresses were available and 1,163 postcards to those for whom only mailing addresses were available. The campuses were largely small liberal arts colleges in the U.S., many in Appalachia, including some elite institutions and two historically Black universities. Liberal arts colleges, such as the ones attended by participants in this sample, tend to provide more opportunities for interaction with diverse others than other types of colleges and universities (Hu \& Kuh, 2003).

Respondents totaled 1,066 (70\% female; 75\% White), representing a $32 \%$ response rate. A design flaw in a small number of survey items resulted in some participants not completing questions that offered nine options instead of five, with 680 participants (63\%) completing all measures (a $21 \%$ response rate). Response rates obtained in this study are in line with response rates achieved in other online surveys (see Nulty, 2008, for a review). In each analysis, the sample size was the maximum number of respondents available given the available data for the variables included in the analysis. The age range of alumni who responded to the survey was between 22 and 50, with a mean age of 29 and a modal age of 32 , with $10 \%$ of the sample older than 35. The average alumni respondent was 9 years post-graduation.

\section{Measures Representing Modeled Variables}

The questionnaire designed for use in the $20^{\text {th }}$ Anniversary Bonner Scholars Survey included items about past college activities and experiences as well as current activities and opinions related to personal and professional life. Past college activities and experiences included participation in Bonner leadership activities; types of co-curricular service experiences; enrollment in curricular SL; types and perceived value of reflection activities; and perceived value of conversations and interactions with Bonner Scholars, faculty, and peers in formal and informal settings who supported learning. One survey question asked about the importance for their learning of "people who were very different from me." Current activities and opinions included benefits of the BSP, attitudes about work, employment sector, level of college debt, life satis- faction, participation in national service programs, and volunteer and voting patterns (Bonner Foundation, 2016). For the purposes of the Pathways to Adult Civic Engagement (PACE) model, and this current article, we focused on understanding the key variables during college that led to civicminded orientations, volunteering, and civic activities in post-college life.

Curricular and co-curricular SL. Bonner alumni reported on the number of SL courses they took during college, ranging from 0 to 11 or more. Sixtysix percent of respondents had taken at least one SL course. Only $16 \%$ of respondents completed five or more SL courses, therefore this variable was recoded from 0 to 5 , with 5 representing five or more courses. Alumni indicated the frequency of their participation in co-curricular service and leadership experiences sponsored by the Bonner Program. These frequencies were recoded and converted into $Z$-scores, then summed to create two indexes (Distefano, Zhu, \& Mîndrilă, 2009): immersive service experiences (i.e., service trips, summers of service, international service experiences; Cronbach's $\alpha=.38$ ) and leadership experiences (i.e., Bonner conferences, COOL conferences, regional conferences, training programs; Cronbach's $\alpha=.51$ ). The reliability for these co-curricular experiences was less than optimal. The lower reliabilities might reflect differences in SL program experiences across the 30 campuses or might reflect a need for further development and clarity of these concepts.

Reflection and dialogue. The Bonner program, by design, places a high level of emphasis on reflection and interaction with others. To understand the contributions of these activities to student outcomes, alumni responded to a set of questions about reflection and meaningful conversations with others. These questions included:

- Reflection is intentionally thinking about experience. Reflection includes making meaning from an experience, gaining understanding or insight, and results in taking new action. The next set of questions ask you to think about the types of reflection activities you used during college and which activities you found to be helpful to your learning.

- In college, learning occurs in a variety of ways. When you think back upon your college experience, how valuable were conversations and interactions with others in challenging and supporting your learning?

Bonner alumni responded on a 7-point rating Likert-type scale with higher scores representing more value for each type of reflection and each type of conversation and interactions with others, using 
a range from $1=$ Not at all important to my learning to $7=$ Extremely important to my learning.

From this data, two indexes were created. The variable named formal dialogue and reflection was defined along two dimensions, including classroom experiences ( 3 items; the importance of conversation with faculty in classroom settings, with students in classroom settings, conversations with faculty/staff in formal settings; Cronbach's $\alpha=.71$ ) and structured assignments ( 3 items; the helpfulness of course writing projects to document learning from an experience, structured reflection activities in a class or organization or Bonner program, writing in a journal; Cronbach's $\alpha=.62$ ). Although journal writing can be done in informal settings, many course-based SL experiences require journal writing and therefore it was considered to be a part of formal reflection in this study.

The variable named informal dialogue and reflection was defined along the dimensions of informal dialogue with peers and informal dialogue with faculty/staff. The concept of informal dialogue with peers represented responses across seven items on how important and helpful, for example, were conversations with Bonners in informal settings, conversations with other students in service experiences, and informal dialogue with others (Cronbach's $\alpha=.84)$. The concept of informal dialogue with faculty/staff represented responses across four items on how important and helpful, for example, were conversations with faculty/staff in informal settings and conversations with a mentor or advisor (Cronbach's $\alpha=.73$ ). The variable of dialogue across difference was defined by responses to a single item about the importance of conversations with others who are very different from me. The survey did not specify the types of difference across which alumni would have had these conversations, simply conversations with people the alumni perceived were different from them on any dimension.

Civic outcomes. Questions regarding the civic outcomes of the BSP included the Civic-Minded Professional Scale (CMP; Hatcher, 2008), three items from Vogelgesang and Astin's (2000) Life After College survey, and 12 items from AmeriCorps's alumni survey (Corporation for National and Community Service, 2004). The CMP scale is comprised of 23 items (Cronbach's $\alpha=.91$ ) and assesses professionals' identity, dispositions, and commitments related to civic action for the public good. Items include statements such as my personal values and beliefs are well integrated and aligned with my work and career and I feel very comfortable recruiting others to become more involved in the community. Alumni rated their agreement with these statements on a 7-point Likert-type scale from 1 = Strongly
Disagree to $7=$ Strongly Agree, with higher average scores representing high levels of civic orientation as a professional $(M=5.65, S D=.75)$.

Alumni also indicated their current levels of voluntary and civic action in their community. Alumni indicated (h)ow many different organizations have you volunteered through in the last 12 months? Seventy-seven percent of alumni reported volunteering in one or more organizations within the past year, and $2 \%$ reported volunteering in eight or more organizations. The number of organizations within which alumni volunteered served as a measure of current levels of voluntary action $(M=2.01, S D=$ 1.69). Each alumnus also indicated the frequency with which she/he had completed a number of civic actions such as contacted public official to express opinion, signed a written or email petition, and didn't buy product because of values of company, on a 7-point rating scale with $1=$ Never and $7=\mathrm{Al}$ ways. The average response across 12 civic actions $(M=3.21, S D=1.21)$ served as an index of current civic engagement (Cronbach's $\alpha=.87$ ).

\section{Results}

The data from the $20^{\text {th }}$ Anniversary Bonner Scholars Study gave us the opportunity to analyze a large data set, explore patterns among variables, and develop the Pathways to Adult Civic Engagement (PACE) model. After mining the extensive survey data in a graduate research class, for developing the PACE model and this current article we focused on understanding the key variables during college that led to civic-minded orientations, volunteering, and civic activities in adult life. We investigated not simply whether the components of the model independently contributed to civic outcomes but also to what extent the interactions among components were influential in producing civic outcomes. A general model emerged from analysis of the data (Figure 1).

\section{Civic Outcomes}

Having a civic-minded orientation, as measured by the CMP scale, was associated with more frequent civic action and with volunteering after graduation. BSP alumni who reported higher levels of civic-minded orientation also reported participating more frequently in a variety of civic actions $[r(681)$ $=.51, p<.001]$ and reported volunteering for a greater number of different organizations within the past 12 months $[r(679)=.40, p<.001]$. Thus, the development of professional orientations that integrate civic identity and work (CMP) was associated with current civic action. 
Figure 1

\section{Pathways to Adult Civic Engagement (PACE) Model}

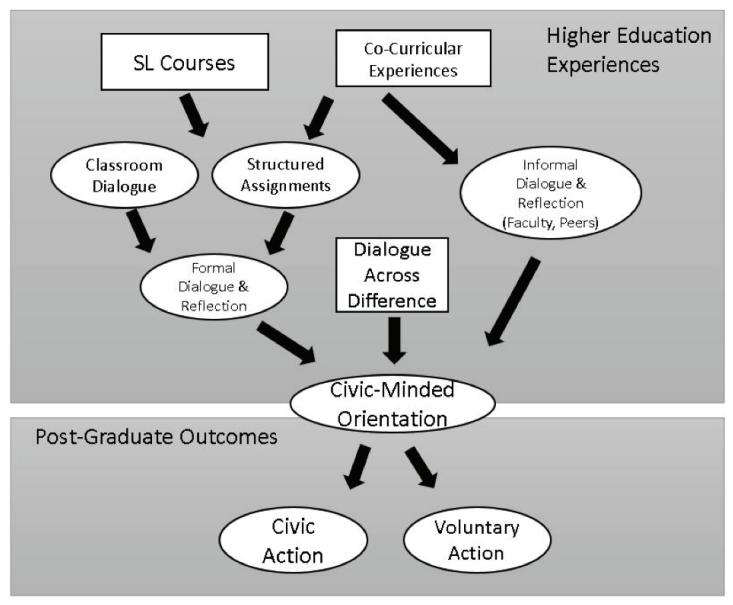

Table 1

Correlations among Civic Outcomes

\begin{tabular}{lcccc}
\hline & $\begin{array}{c}\text { Civic } \\
\text { Civic-minded } \\
\text { Orientation }\end{array}$ & $\begin{array}{c}\text { Action } \\
\text { Index }\end{array}$ & $M$ & $S D$ \\
\hline $\begin{array}{c}\text { Civic-minded } \\
\text { Orientation }\end{array}$ & & & 5.65 & .75 \\
$\begin{array}{c}\text { Civic Action } \\
\text { Index }\end{array}$ & $.51^{* *}$ & & 3.21 & 1.31 \\
$\begin{array}{c}\text { Voluntary } \\
\text { Action }\end{array}$ & $.40^{* *}$ & $.36^{* *}$ & 2.01 & 1.69 \\
\hline
\end{tabular}

Note: $* * p<.001$ (2-tailed).

\section{Dialogue across Difference}

The PACE model suggests the central importance of asking college students to reflect upon their conceptions about the community and about their place in it. An important mechanism in this process, as proposed by the PACE model, is engaging during college in challenging dialogue across perceived difference. To test this influence on future alumni civic action, we conducted a mediation analysis (Baron \& Kenny, 1986). The more BSP alumni rated dialogue with people who were very different from me as important to their learning during their college experiences the more frequently these alumni reported currently engaging in different types of civic action $[r(653)=.30, p<.001]$ and the more they reported volunteering at a number of different community organizations $[r(657)=.15, p$ $=.001]$. Thus, the more BSP alumni found dialogue across difference important during their college experiences (across curricular and co-curricular SL programs), the more they were committed to volunteering and civic action after graduation. Dialogue with people "who were very different" also was strongly associated with responses on the CMP scale $[r(654)=.45, p=.001]$, suggesting that dialogue across difference was supportive of the development of a civic-minded orientation to one's work life.

Figures 2A and 2B show the mediation model with coefficients for the relationship between dialogue across difference and civic action when the relationship with CMP is statistically controlled. Sobel tests and resulting coefficients indicate that the relationship between dialogue across difference and civic actions was not mediated, but the magnitude of the relationship was modified or moderated by CMP $(Z=9.04, p<.001)$. The relationship between dialogue across difference and volunteering, on the other hand, was completely mediated by CMP, $Z=7.94, p<.001$ (see Figures $2 \mathrm{~A}$ and $2 \mathrm{~B}$ for coefficients). Thus, the relationship between meaningful dialogues across difference during college was related to civic and voluntary action after graduation when those dialogues contributed to a deep sense of professional commitment to civic action and service.

Figures 2A and 2B

Civic-Minded Orientations Moderate the

Relationship between Dialogue across Perceived

Difference and Civic Action (Figure 2A) and

Mediates the Relationship between Dialogue across Difference and Voluntary Action

(Figure 2B)

Figure 2A

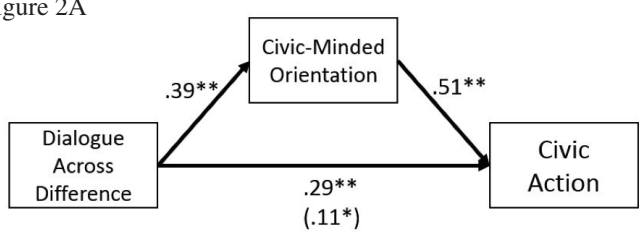

Figure 2B

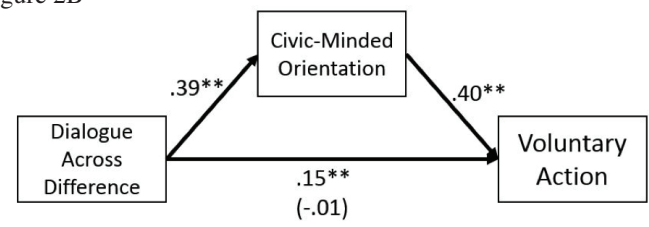

Note. Coefficients represent standardized estimates with partial coefficients in parentheses.

$* p<.05 ; * * p<.001$.

\section{Reflection and Dialogue}

The development of commitments to civic action through personal and professional identity depends on a number of factors, only some of which relate 
Table 2

Bivariate Correlations indicating Associations among Various types of Reflection and Dialogue during College Civic-Minded Orientation after Graduation

\begin{tabular}{|c|c|c|c|c|c|}
\hline & $\begin{array}{l}\text { Civic-minded } \\
\text { Orientation }\end{array}$ & $\begin{array}{c}\text { Dialogue Across } \\
\text { Difference }\end{array}$ & $\begin{array}{l}\text { Classroom } \\
\text { Experiences }\end{array}$ & $\begin{array}{l}\text { Structured } \\
\text { Assignments }\end{array}$ & $\begin{array}{l}\text { Peer Informal } \\
\text { Dialogue }\end{array}$ \\
\hline Dialogue Across Difference & $.44 * *$ & & & & \\
\hline Classroom Experiences & $.32 * *$ & $.57 * *$ & & & \\
\hline Structured Assignments & $.27 * *$ & $.36^{* *}$ & $.34 * *$ & & \\
\hline Peer Informal Dialogue & $.40^{* *}$ & $.66^{* *}$ & $.56 * *$ & $.47 * *$ & \\
\hline \multicolumn{6}{|l|}{ Faculty/Staff } \\
\hline Informal Dialogue & $.37^{* *}$ & $.54 * *$ & $.70^{* *}$ & $.31 * *$ & $.53 * *$ \\
\hline
\end{tabular}

Note. $* * p<.001$

Table 3

Simultaneous Regression Predicting Civic-Minded Orientation after Graduation from Various types of Reflection and Dialogue during College.

\begin{tabular}{lrrrrr}
\hline & $B$ & $S E$ & $\beta$ & $t$-value & Tolerance \\
\hline (Constant) & 3.69 & .15 & & & \\
Dialogue Across Diff & .16 & .03 & .27 & $5.34^{* *}$ & .49 \\
Classroom Experiences & -.03 & .03 & -.04 & -.85 & .45 \\
Structured Assignments & .04 & .02 & .08 & $2.08^{*}$ & .77 \\
Peer Informal Dialogue & .09 & .04 & .13 & $2.49^{*}$ & .46 \\
Faculty/Staff & .10 & .03 & .16 & $3.18^{* *}$ & .47 \\
\hline Informal Dialogue & & & & & \\
\hline
\end{tabular}

Notes. Dependent Variable $=$ Civic-minded Orientation;

$B=$ Unstandardized Coefficients, $S E=$ Standard Error, $\beta=$ Standardized Coefficients

$* p<.05 ; * * p<.01, * * * p<.01$

to dialogue across difference. Students find opportunities to engage in dialogue and reflection in SL courses, co-curricular programming, and many other college experiences. We tested the interrelationships among reported dialogue and conversations alumni reported across a number of academic and co-curricular experiences in college with civic-minded orientation using multiple regression analyses. Table 2 provides a summary of the bivariate correlations among the included variables, and Table 3 provides the multiple regression analysis results. Overall, reports of valuable dialogue during college experiences predicted civic-minded orientations after graduation, Adjusted $R^{2}=.23$, $F(5,624)=39.18, p<.001$. Among the various opportunities for reflection and dialogue (see Table 3 ), the best predictor of a civic-minded orientation after graduation was the opportunity to dialogue with people who were very different $(\beta=.27)$. The only type of dialogue that was not related to a civicminded orientation (while controlling for other forms of reflection and dialogue) was structured reflection and dialogue as part of a course $(\beta=-.04)$. The lack of relationship with course reflection and dialogue, however, might be a function of the interrelationship among course-related dialogue and informal dialogue with faculty and staff as well as with dialogue across perceived difference (see Ta- ble 2). In addition, the alumni from the first decade of the 20-year BSP likely had fewer opportunities to take SL courses, as the number of such courses likely increased over time.

\section{Curricular and Co-curricular SL Support Civic- Minded Orientations}

Reflection and dialogue are supported by curricular and co-curricular SL experiences during college. To investigate the relationship among these experiences and their connection with the development of a civic-minded orientation, we employed hierarchical regression. Table 4 provides bivariate correlations among curricular and co-curricular SL experiences and a civic-minded orientation (CMP). Table 5 provides coefficients for both a simultaneous regression and a hierarchical regression controlling for reflection and dialogue variables listed in Table 3. This analysis determines the unique contribution of taking SL courses and participating in co-curricular programming when dialogue and reflection during these experiences are statistically allowed to influence the results (simultaneous regression) and when reflection and dialogue during these experiences are specifically controlled in the analysis, showing the unique contribution of coursework and co-curricular experiences without 
Table 4

Various types of Reflection and Dialogue during College Correlated with Civic-

Minded Orientation after Graduation

\begin{tabular}{lccc}
\hline & CMP & SL Courses & $\begin{array}{c}\text { Immersive Service } \\
\text { Experiences }\end{array}$ \\
\hline SL Courses & $.15^{* *}$ & & \\
Immersive Service Exp. & $.15^{* *}$ & $.12^{* *}$ & \\
Leadership Experiences & $.28^{* *}$ & $.26^{* *}$ & $.16^{* *}$ \\
\hline
\end{tabular}

Notes. $\mathrm{CMP}=$ Civic-Minded Professional score; $\mathrm{SL}=$ Service Learning

$* * p<.001$

Table 5

Simultaneous Regression Predicting Civic-Minded Orientation after Graduation from the

Frequency of Service Learning (SL) Courses and the Frequency of Co-Curricular Experiences

(Model 1) and Hierarchical Regression while Controlling for Reflection and Dialogue (Model 2)

\begin{tabular}{lrrrrr}
\hline \multicolumn{1}{c}{ Model 1 } & $B$ & $S E$ & $\beta$ & $t$-value & Tolerance \\
\hline (Constant) & 4.48 & .16 & & & .93 \\
SL Courses & .03 & .02 & .08 & 1.93 & .93 \\
Immersive Service Exp. & .15 & .04 & .11 & $2.75^{* *}$ & .97 \\
Leadership Experiences & .22 & .04 & .24 & $6.16^{* * *}$ & .92
\end{tabular}

Model 2

\begin{tabular}{lrllll}
\hline (Constant) & 3.87 & .15 & & & \\
SL Courses & .01 & .02 & .03 & .78 & .93 \\
Immersive Service Exp. & .08 & .04 & .10 & $2.33^{*}$ & .97 \\
Leadership Experiences & .10 & .03 & .12 & $2.90^{* *}$ & .92 \\
\hline
\end{tabular}

Notes. Dependent Variable $=$ Civic-Minded Professional score;

$B=$ Unstandardized Coefficients, $S E=$ Standard Error, $\beta=$ Standardized Coefficients

$* p<.05 ; * * p<.01, * * * p<.01$

the influence of reflection and dialogue.

The frequency of taking SL courses in college was associated with a civic-minded orientation after graduation, $r(646)=.15, p<.001$ (see Table 4$)$. For Bonner alumni, however, a civic-minded orientation was more strongly associated with Bonner leadership experiences $(r(646)=.28, p<.001$. Students enrolled in the BSP likely engage in leadership experiences and SL courses simultaneously. The simultaneous regression analysis indicates that curricular SL and co-curricular SL experiences overall were associated with a civic-minded orientation after graduation, $R^{2}=.09, F(3,644)=22.32$, $p<.001$. When reflection activities were specifically controlled to determine the unique influence of curricular SL and co-curricular SL experiences, the hierarchical regression indicates that these college-level experiences continue to predict a civic-minded orientation after graduation $\left[R^{2}=.03\right.$, $F(3,595)=6.36, p<.001]$, albeit a smaller amount. An examination of the pattern of coefficients indicates that the relationship between leadership experiences and immersive service experiences during college with a civic-minded orientation exists beyond what could be accounted for by the reflection and dialogue experiences involved in these experiences. One interpretation of the pattern of coefficients is that the influence of SL courses on a civicminded orientation after graduation seems to occur through the reflection, dialogue activities, and assignments associated with those course-based experiences.

\section{Discussion}

Research on SL, particularly course-based SL, has engendered much attention, and this study suggests that SL, particularly co-curricular SL, provides a rich learning environment for civic outcomes after college. SL provides opportunities for both formal and informal reflections and conversations with others. These conversations occur with peers, faculty, community members, or community site supervisors, and may involve dialogue across difference. These conversations, both formal and informal, may promote moral and cognitive reflection at service sites, in the classroom, and in informal discussion settings on campus or in the van going to or returning from service sites. The PACE model emphasizes the importance of reflection and 
dialogue as it provides opportunities for the development of a civic orientation toward and commitment to service in one's community.

Barnhardt, Sheets, and Pasquesi (2015) found that liberal arts colleges with a mission reflecting commitment to service, typical of BSP host institutions, might be more successful at developing civic action in their alumni than comprehensive undergraduate institutions and research-focused institutions. The Wabash alumni study (Kilgo et al., 2014), however, found that doing course-based SL might contribute more to sustaining civic outcomes than pre-college service experiences. SL experiences with adequate opportunities for dialogue and reflection may prevent the modest decline in civic engagement after college. Further research could establish whether the relationship among program elements and civic outcomes might be maintained outside of the unique mission of liberal arts schools.

\section{Limitations}

In the current project, dialogue across difference served as a key experience in predicting civic orientations and civic action after graduation, yet this was based on a single-item measure. The development of a pluralistic orientation (see Engberg \& Hurtado, 2011), for example, might mediate some of the effects that dialogue across difference has in predicting civic engagement after college. We have limited data about the developmental experiences in young adulthood (Arnett, 2004) that might influence civic engagement after college. Bonner Scholars may have pursued uniquely developmental experiences. Future research could establish additional variables that are important for these program elements to have their full effect. The Difficult Dialogues project (O'Neil, 2006; Placier, Kroner, Burgoyne, \& Worthington, 2012) sponsored by the Ford Foundation has worked to develop successful practices to sustain dialogues on campus among students who perceive important differences going into the dialogues in both curricular and co-curricular settings.

The $20^{\text {th }}$ Anniversary Bonner Scholars Survey formatively evaluated the BSP program, and this might limit the applicability of findings to other colleges' co-curricular and service-based scholarship program. The constructs of 'leadership' and 'immersive service experiences' were based on specific questions related to BSP programs. This may have led to an undue emphasis on these types of experiences. The alumni answered many questions about their current practices, and the relationships among a variety of program experiences and current behavior suggest the importance of these program variables. Future research could explore additional program attributes of theoretical interest along with attributes identified in the current study to explore possible overlap or extension of concepts related to civic action after graduation.

Common to prior research on SL in classes or programs into which students self-select, this study was based on data from college graduates who either self-selected to apply for the BSP or were selected by admissions offices to be a part of this service-based scholarship program. Participants also self-selected to participate in the study. This self-selection bias may have influenced the results in that respondents may have been among those BSP alumni who were most satisfied with their Bonner experience. The best way to control for self-selection bias in quasi-experimental designs is to control for pre-existing variables; however, this approach was not possible in that we did not have any information about the participants before college. One way to address the concern about response bias due to self-selection is to ensure a reasonable response rate, which we were able to establish. Additionally, the pattern of the correlations suggest, however, that higher amounts of reflection, dialogue, and SL experiences were associated with higher amounts of civic outcomes in one's adult and professional lives, even for those who self-selected into the program.

\section{Implications}

These findings are particularly relevant to advancing the use of service-based scholarships as curricular or co-curricular strategy for engaging students in developmentally conducive learning opportunities and institutional strategy for developing civic-minded alumni, particularly among college students who are Pell Grant eligible, which is the case for most Bonner Scholars. Findings from this current study are consistent with those from the Sam H. Jones Community Service Scholarship (Hatcher, Bringle, Brown, \& Fleischhacker, 2006), a campus-funded program at Indiana UniversityPurdue University Indianapolis (Hahn, Hatcher, \& Graunke, 2016). Evidence from both studies indicates that service-based scholarship programs provide opportunities for high-ability low-income students to be successful in college and in professional life. Many foundations (e.g., Lumina) are interested in finding ways to improve degree completion among low-income students. Similarly, as states move toward outcome metrics in higher education, one of the metrics to determine performance funding for public institutions may be based on the number of students with a Pell Grant who complete a bachelor's degree. 
The PACE model suggests that faculty and staff need to provide opportunities for informal dialogue with faculty and peers, particularly if they want educational experiences to result in civic-minded alumni. Our findings bear out decades-long research by Astin (1993) showing the importance of informal discussion with peers as well as by Schoem and Hurtado (2001) who documented the outcomes of dialogue across boundaries of perceived difference. Whereas informal reflection appears prominently in the PACE model, we learned that structured and unstructured reflection work together to support civic outcomes.

The Civic-Minded Professional (CMP; Hatcher, 2008) scale, previously validated with a sample of higher education faculty, shows promise as an instrument for studying civic-mindedness among alumni and across a range of professional fields. In the current study, scores on the CMP scale were strongly associated with measures of volunteerism and civic action among BSP alumni years after graduation. Researchers interested in evaluating the long-term community impact of SL courses and co-curricular programs might consider assessing the extent to which a civic-minded orientation leads to community benefit through the civic actions of their alumni.

Research on higher education, as with research on K-12 education, also suggests that teaching approaches that stress collaborative and experiential work and projects, including group inquiry, political internships, simulations, and open and critical discussion, are often important for promoting civic learning and civic action in college students (Astin, 1993; Battistoni \& Hudson, 1997; Beaumont, 2012; Kuh et al., 2005). Although extensive research is available on SL, dialogue across difference is not often included in quantitative collection tools nor in observations or interview protocols. Even more challenging might be arranging college classes, enrollment, and major selection so that such perceived diversity, as well as reflection and dialogue regarding those differences, is part of students' experiences.

When changing the mission and sustaining a commitment to fostering civic engagement amongst graduates seems too far a reach, the PACE model suggests that smaller program designs can bring desired results to a cohort within a larger institution. Coordinated programs at the institutional level and across institutions can be difficult to implement and manage. Smaller programs that include a coordinated set of key elements referenced by the PACE model may find success with a smaller number of students. This general PACE model likely has its greatest impact as programs across multiple institu- tions and settings find ways to emphasize these key elements as a way of fostering and encouraging a civic-minded orientation among their program participants, graduates, and future professionals.

\section{Notes}

BSP campuses participating in the study include Allegheny College, Berea College, Berry College, Carson-Newman College, Centre College, Concord College, Davidson College, Earlham College, Ferrum College, Guilford College, Lees-McRae College, Lynchburg College, Mars Hill College, Maryville College, Middlesex County College, Morehouse College, Oberlin College, Rhodes College, Spelman College, Stetson University, The College of New Jersey, University of Richmond, Warren Wilson College, Waynesburg University, West Virginia Wesleyan College, and Wofford College.

\section{References}

American Association of College and Universities (AAC\&U). (2009). Civic engagement VALUE rubrics. Retrieved from https://www.aacu.org/civic-engage ment-value-rubric.

Arnett, J. J. (2004). Emerging adulthood: The winding road from the late teens through the twenties. New York: Oxford University Press.

Ash, S. L., \& Clayton, P. H. (2004). The articulated learning: An approach to guided reflection and assessment. Innovative Higher Education, 29(2), 137-154. https://doi.org/10.1023/B:IHIE.0000048795.84634.4a

Astin, A. W. (1993). What matters in college. San Francisco: Jossey-Bass.

Astin, A. W., \& Sax, L. J. (1998). How undergraduates are affected by service participation. Journal of College Student Development, 39(3), 251-263.

Astin, A.W., Vogelgesang, L. J., Ikeda, E. K.; \& Yee, J. A. (2000). How service learning affects students. Retrieved from http://heri.ucla.edu/pdfs/hslas/hslas.pdf.

Barnhardt, C. L., Sheets, J. E., \& Pasquesi, K. (2015). You expect what? Students' perceptions as resources in acquiring commitments and capacities for civic engagement. Research in Higher Education, 56, 622644. https://doi.org/10.1007/s11162-014-9361-8

Baron, R. M., \& Kenny, D. A. (1986). The moderatormediator variable distinction in social psychological research: Conceptual, strategic, and statistical considerations. Journal of personality and social psychology, 51(6), 1173-1182. https://doi.org/10.1037/00223514.51.6.1173

Battistoni, R. M., \& Hudson, W. E. (1997). Experiencing citizenship: Concepts and models for service-learning in political science. Stylus Publishing, LLC.

Baxter Magolda, M. B. (2000). Interpersonal maturity: Integrating agency and communion. Journal of College Student Development, 41(2), 141-156. 
Beaumont, E. (2012). What does recent research suggest about civic learning and civic action in young adults 18-30? Some insights and foundations for further work. Spencer Foundation. Retrieved from http:// www.spencer.org/resources/content/3/9/2/documents/ elizabethbeaumont.pdf

Blaich, C. F., Pascarella, E. T., Wolniak, G. C., \& Cruce, T. M. (2004). Do liberal arts colleges really foster good practices in undergraduate education? Journal of College Student Development, 45(1), 57-74. https:// doi.org/10.1353/csd.2004.0013

Bonner Network (2015). Student development and leadership. Retrieved from http://bonnernetwork.pbworks. com/w/page/13113175/Student\%20Development\%20 and\%20Leadership.

Bonner Foundation (2016). Student Impact Survey. Retrieved from http://bonnerwikiv2.pbworks.com/w/ page/104743603/Bonner\%20Student\%20Impact\%20 Survey\%20-\%200verview .

Boss, J. A. (1994). The effect of community service work on the moral development of college ethics students. Journal of Moral Education, 23(2), 183-198. https://doi.org/10.1080/0305724940230206

Bowman, N. A. (2011). Promoting participation in a diverse democracy A meta-analysis of college diversity experiences and civic engagement. Review of Educational Research, 81(1), 29-68. https://doi. org/10.3102/0034654310383047

Bowman, N. A., \& Brandenberger, J. W. (2012). Experiencing the unexpected: Toward a model of college diversity experiences and attitude change. The Review of Higher Education, 35(2), 179-205. https://doi. org/10.1353/rhe.2012.0016

Bowman, N., Brandenberger, J., Lapsley, D., Hill, P., \& Quaranto, J. (2010). Serving in college, flourishing in adulthood: Does community engagement during the college years predict adult well-being? Applied Psychology: Health and Well-Being, 2(1), 14-34. https:// doi.org/10.1111/j.1758-0854.2009.01020.x

Bowman, N. A., Park, J. J., \& Denson, N. (2015). Student involvement in ethnic student organizations: Examining civic outcomes 6 years after graduation. $R e$ search in Higher Education, 56, 127-145. https://doi. org/10.1007/s11162-014-9353-8

Bringle, R. G., \& Hatcher, J. A. (1999). Reflection in service-learning: Making meaning of experience. $E d$ ucational Horizons, 77, 179-185.

Brookfield, S. (1995). Becoming a critically reflective teacher. San Francisco: Jossey-Bass.

Butin, D. W. (2013). Transformation is just another word: Thinking through the future of community engagement in the disrupted university. In A. Hoy \& M. Johnson (Eds.), Deepening community engagement in higher education (pp. 245-252). New York: Palgrave Macmillan.

Checkoway, B. (2014). Civic minded professors. In J. Reich (Ed.), Civic engagement, civic development, and higher education (pp. 77-79). Washington, DC: Bringing Theory to Practice.

Civic Rubrics for Knowledge and Values: A National
Collaboration. (2016). Civic Knowledge Rubric. Retrieved from https://civiclearningrubric.wordpress. com/civic-knowledge-rubric/

Colby, A., Ehrlich, T., Beaumont, E., \& Stephens, J. (2003). Educating citizens: Preparing America's undergraduates for lives of moral and civic responsibility. San Francisco: Jossey-Bass.

Conway, J. M., Amel, E. L., \& Gerwien, D. P. (2009). Teaching and learning in the social context: A meta-analysis of service-learning's effects on academic, personal, social, and citizenship outcomes. Teaching of Psychology, 36, 233-245. https://doi. org/10.1080/00986280903172969

Corporation for National and Community Service (2004). Serving country and community: A longitudinal study of service in AmeriCorps (Report). Cambridge, MA, Abt Associates.

Council for the Advancement of Standards in Higher Education (2015). Civic engagement and servicelearning programs. Retrieved from http://standards. cas.edu/getpdf.cfm?PDF=E86EC8E7-9B94-5F5C9AD22B4FEF375B64

Daloz, L. A., Keen, C. H., Keen, J. P., \& Parks, S. D. (1996). Common fire: Lives of commitment in a complex world. Boston: Beacon Press.

Diaz, A., \& Perrault, R. (2010). Sustained dialogue and civic life: Post-college impacts. Michigan Journal of Community Service Learning, 17(1), 32-43.

Distefano, C., Zhu, M., \& Mîndrilă, D. (2009). Understanding and using factor scores: Considerations for the applied researcher. Practical Assessment, Research \& Evaluation, 14(20), 1-11.

Dzur, A. W. (2004). Democratic professionalism: Sharing authority in civic life. The Good Society, 13(1), 614. https://doi.org/10.1353/gso.2004.0026

Engberg, M. E., \& Hurtado, S. (2011). Developing pluralistic skills and dispositions in college: Examining racial/ethnic group differences. The Journal of Higher Education, 82, 416-443. https://doi.org/10.1353/ jhe. 2011.0025

Eyler, J., \& Giles Jr, D. E. (1999). Where's the learning in service-learning? San Francisco: Jossey-Bass.

Fenzel, L. M., \& Peyrot, M. (2005). Comparing college community participation and future service behaviors and attitudes. Michigan Journal of Community Service-learning, 12(1), 23-31.

Finlay, A. K., Flanagan, C., \& Wray-Lake, L.(2011). Civic engagement patterns and transitions over 8 years: The AmeriCorps national study. Developmental Psychology, 47(6), 1728-1743. https://doi.org/10.1037/ a0025360

Finley, A. (2011). Civic learning and democratic engagements: A review of the literature on civic engagement in post-secondary education. Paper prepared for the U. S. Department of Education as part of Contract: EDOPE-10_C-0078. Retrieved from http://www.aacu. org/sites/default/files/files/CLDE/LiteratureReview. pdf

Finley, A., \& McNair, T. (2013). Assessing underserved students' engagement in high impact practices. (Re- 
port) Washington D.C.: American Association of College and Universities.

Giles, Jr., D. E., \& Eyler, J. (2013). Review essay: The endless quest for scholarly respectability in servicelearning research. Michigan Journal of Community Service Learning, 20(1), 53-64.

Gurin, P., Dey, E. L., Hurtado, S., \& Gurin, G. (2002). Diversity in higher education: Theory and impact on educational outcomes. Harvard Educational Review, 72(3), 330-366. https://doi.org/10.17763/ haer.72.3.01151786u134n051

Hahn, T. W. \& Hatcher, J. A. (2015). The relationship between enrollment in service learning courses and deep approaches to learning: A campus study. PRISM: A Journal of Regional Engagement, 4 (2), 55-70. Retrieved from http://encompass.eku.edu/prism/vol4/iss2/1.

Hahn, T. W., \& Hatcher, J. A. (2015, September 30). What about service-learning matters? Using a taxonomy to identify variables to improve research and practice [Webinar]. In IARSLCE Webinar Series. Retrieved from https://www.youtube.com/watch?v=03W27s3XTw.

Hahn, T. W., Hatcher, J. A., \& Graunke, S. S. (2016). Service scholarships, persistence and retention. Research Brief, Center for Service and Learning, Indianapolis, IN.

Hatcher, J. A. (2008). The public role of professionals: Developing and evaluating the Civic-Minded Professional scale. (Doctoral dissertation). Retrieved from Pro Quest Dissertation and Theses, AAT 3331248, 2008.

Hatcher, J. A. (2011). Civic knowledge and engagement. In J. Penn (Ed.), Measuring complex general education learning outcomes. Jossey-Bass Quarterly Sourcebooks (pp. 81-92). San Francisco: Jossey-Bass.

Hatcher, J. A., Bringle, R. G., Brown, L. A., \& Fleischhacker, D. A. (2006). Indiana University-Purdue University Indianapolis: Supporting student involvement through service-based scholarships. In E. Zlotkowski, N. V. Longo, \& J. R. Williams (Eds.), Students as colleagues: Expanding the circle of service-learning leadership (pp. 35-48). Providence, RI: Campus Compact.

Hatcher, J. A., Bringle, R. G., \& Hahn, T. W. (2016). Research on student civic outcomes in service learning: Conceptual frameworks and methods. Volume 3: IUPUI Series on Service Learning Research. Sterling, VA: Stylus Publishing.

Hatcher, J. A., Bringle, R.G., \& Muthiah, R. (2004). Designing effective reflection: What matters to servicelearning? Michigan Journal of Community Service learning, 11(1), 38-46.

Hemer, K. M., \& Reason, R. D. (2016, in press). Civic outcomes in higher education. In J. A. Hatcher, R.G. Bringle, \& T. W. Hahn (Eds.), Research on student civic outcomes in service learning: Conceptual frameworks and methods (pp. 25-43). Sterling, VA: Stylus.

Holsapple, M. A. (2012). Service-learning and student diversity outcomes: Existing evidence and directions for future research. Michigan Journal of Community Service Learning, 18(2), 5-18.
Hudson, M., \& Hunter, K. O. (2014). Positive effects of peer-led reflection on undergraduates' concept integration and synthesis during service-learning. International Journal of Teaching and Learning in Higher Education, 26(1), 12-25.

Hu, S., \& Kuh, G. D. (2003). Diversity experiences and college student learning and personal development. Journal of College Student Development, 44(3), 320 334. https://doi.org/10.1353/csd.2003.0026

Jacoby, B. (2015). Service-learning essentials: Questions, answers, and lessons learned. San Francisco: Jossey-Bass.

Jones, S. R., Robbins, C. K., \& LePeau, L. A. (2011). Negotiating border crossing: Influences of social identity on service-learning outcomes. Michigan Journal of Community Service Learning, 17(2), 27-42.

Jones, S. R., \& Abes, E. S. (2004). Enduring influences of service-learning on college students' identity development. Journal of College Student Development, 45(2), 149-166. https://doi.org/10.1353/csd.2004.0023

Jones, S. R., \& Hill, K. E. (2003). Understanding patterns of commitment: Student motivation for community service involvement. The Journal of Higher Education, 74(5), 516-539. https://doi.org/10.1353/ jhe.2003.0036

Keeling, R. (Ed.). (2004). Learning reconsidered: A campus-wide focus on the student experience. Washington, DC: American College Personnel Association and National Association of School Personnel Administrators.

Keen, C., \& Hall, K. (2009). Engaging with difference matters: Longitudinal student outcomes of co-curricular service-learning programs. The Journal of Higher Education, 80(1), 59-79. https://doi. org/10.1353/jhe. 0.0037

Kilgo, C. A., Pasquesi, K., Sheets, J. K. E., \& Pascarella, E. T. (2014). The estimated effects of participation in service-learning on liberal arts outcomes. The International Journal of Research on Service-Learning and Community Engagement, 2(1), 18-31.

Kim, T, Flanagan, C. A. \& Pykett, A. A. (2015). Adolescents' civic commitments in stable and fledgling democracies: The role of family, school, and community. Research in Human Development, 12(1), 28-43. https://doi.org/10.1080/15427609.2015.1010344

Knefelkamp, L. (2008). Civic identity: Locating self in community. Diversity and Democracy: Civic Learning for Shared Futures, 11(2), 1-3.

Kuh, G. D., Kinzie, J., Schuh, J. H., \& Whitt, E. J. (2005). Never let it rest: Lessons about student success from high-performing colleges and universities. Change: The Magazine of Higher Learning, 37(4), 44-51. https://doi.org/10.3200/CHNG.37.4.44-51

Mabry, J. B. (1998). Pedagogical variations in servicelearning and student outcomes: How time, contact and reflection matters. Michigan Journal of Community Service Learning, 5,32-47.

Mezirow, J. (2000). Learning as transformation: Critical perspectives on a theory in progress. San Francisco: Jossey-Bass. 
Mitchell, T. D. (2014). How service-learning enacts social justice sensemaking. Journal of Critical Thought and Praxis, 2(2), 1-26.

Mitchell, T. D., Battistoni, R. M., Keene, A. S. \& Reiff, J. (2013). Programs that build civic identity: A study of alumni. Diversity and Democracy, Summer, 16(3), 22-23.

Mitchell, T. D., Richard, F. D., Battistoni, R. M., RostBanik, C., Netz, R., \& Zakoske, C. (2015). Reflective practice that persists: Connections between reflection in service-learning programs and in current life. Michigan Journal of Community Service Learning, 21(2), 49-64.

Morton, K., \& Bergbauer, S. (2015). A case for community: Starting with relationships and prioritizing community as method in service-learning. Michigan Journal of Community Service Learning, 22(1), 18-32.

National Task Force on Civic Learning and Democratic Engagement. (2012). A crucible moment: College learning and democracy's future. Washington, DC: Association of American Colleges and Universities.

National Youth Leadership Council (2008). K-12 servicelearning standards for quality practice. Retrieved from https://nylc.org/standards/

Niehaus, E., \& Rivera, M. (2015). Serving a stranger or serving myself: Alternative breaks and the influence of race and ethnicity on student understanding of themselves and others. Journal of College and Character, 16, 209-224. https://doi.org/10.1080/219458 $7 X .2015 .1091360$

Nulty, D. (2008). The adequacy of response rates to online and paper surveys: What can be done? Assessment \& Evaluation in Higher Education, 33(3), 301-314. https://doi.org/10.1080/02602930701293231

O'Neil, R. M. (2006). The difficult dialogues initiative. Academe, 92(4), 29-30. https://doi. org/10.2307/40253462

Placier, P., Kroner, C., Burgoyne, S., \& Worthington, R. (2012). Developing difficult dialogues: An evaluation of classroom implementation. The Journal of Faculty Development, 26(2), 29-36.

Reich, I. N. (Ed.). (2014). Civic engagement, civic development, and higher education: New

perspectives on transformational learning. Washington, D.C.: Bringing Theory to Practice.

Rockenbach, A. B., Hudson, T. D., \& Tuchmayer, J. B. (2014). Fostering meaning, purpose, and enduring commitments to community service in college: A multidimensional conceptual model. The Journal of Higher Education, 85, 312-338. https://doi.org/10.1353/ jhe.2014.0014

Schoem, D. L., \& Hurtado, S. (2001). Intergroup dialogue: Deliberative democracy in school, college, community, and workplace. Ann Arbor, MI: University of Michigan Press. https://doi.org/10.3998/mpub.11280

Schön, D. A. (1987). Educating the reflective practitioner: Toward a new design for teaching and learning in the professions. San Francisco: Jossey-Bass.

Seider, S. (2013). Two key strategies for enhancing community service learning. Journal of College and
Character, 14(1), 79-84. https://doi.org/10.1515/jcc2013-0011

Seider, S., \& Hillman, A. (2011). Challenging privileged college students' othering language in community service learning. Journal of College and Character, 12(3), 1-7. https://doi.org/10.2202/1940-1639.1810

Stokamer, S. T., \& Clayton, P. H. (2016). Civic learning through service learning: Instructional design and research. In J. A. Hatcher, R. G. Bringle, \& T. W. Hahn (Eds.), Research on student civic outcomes in service learning: Conceptual frameworks and methods (pp. 45-65). Sterling, VA: Stylus.

Sullivan, W. M. (2005). Work and integrity: The crisis and promise of professionalism in America ( $2^{\text {nd }}$ Edition). San Francisco: Jossey-Bass.

Sullivan, W. M. \& Rosin, M. S. (2008). A new agenda for higher education: Shaping a life of the mind for practice. San Francisco: Jossey-Bass.

Steinberg, K. S., Bringle, R. G., \& McGuire, L.E. (2013). Attributes of high-quality research on service learning. In P. H. Clayton, R. G. Bringle, \& J. A. Hatcher (Eds.), Research on service learning: Conceptual frameworks and assessment, Vol 2A: Students and Faculty (pp. 2753). Sterling, VA: Stylus.

Steinberg, K., Hatcher, J. A., \& Bringle, R. G. (2011). A north star: Civic-minded graduate. Michigan Journal of Community Service Learning, 18(1), 19-33.

Sturgill, A., \& Motley, P. (2014). Methods of reflection about service-learning: Guided vs. free, dialogic vs. expressive, and public vs. private. Teaching and Learning Inquiry: The ISSOTL Journal, 2(1), 81-93. https://doi.org/10.20343/teachlearninqu.2.1.81

Vogelgesang, L. \& Astin, A. (2000). Comparing the effects of community service and service-learning. Michigan Journal of Community Service Learning, 7, 25-34.

Vogelgesang, L. J., \& Astin, E. W. (2005). Research Report\# 2: Post-college civic engagement among graduates. Higher Education Research Institute: University of California, Los Angeles.

Warren, J. L. (2012). Does service-learning increase student learning?: A meta-analysis. Michigan Journal of Community Service Learning, 18(2), 56-61.

Wilson, J., 2000. Volunteering. Annual Review of Sociology, 26, 215-240. https://doi.org/10.1146/annurev. soc.26.1.215

Yorio, P. L., \& Ye, F. (2012). A meta-analysis on the effects of service-learning on the social, personal, and cognitive outcomes of learning. Academy of Management Learning and Education, 11(1), 9-27. https://doi. org/10.5465/amle.2010.0072

\section{Authors}

DAN RICHARD (drichard@unf.edu) is the director of the Office of Faculty Enhancement and associate professor in the Department of Psychology at the University of North Florida. He also serves as the section co-editor of the Advances in Theory and 
Methodology Section of the International Journal of Research on Service Learning and Community Engagement. He is the lead researcher assessing student-learning outcomes related to UNF's Quality Enhancement Plan on community-based transformational learning. He teaches service-learning courses in research design and statistics as well as a course on revenge and the lasting impact of community resentment on individuals making a transition from prison back to the community.

CHERYL KEEN (cheryl.keen@waldenu.edu) serves as core faculty in the Ph.D. in Education program at Walden University. Previously she served as dean of faculty, co-dean of students, and director of the Center for Community Learning at Antioch College, 15 years as senior researcher for the Bonner Foundation, and several years as evaluator of the Volunteers Exploring Vocation program. Before that she directed the New Jersey Governor's School on Public Issues and the Future of New Jersey, and was the Millicent Fenwick Research Professor for Public Issues and Education at Monmouth University. Cheryl Keen's co-authored book, Common Fire: Leading Lives of Commitment in a Complex World (Beacon Press, 1996), anchors the focus of her scholarly outreach.
JULIE HATCHER (jhatcher@iupui.edu) is executive director of the Center for Service and Learning and associate professor of Philanthropic Studies in the Lilly Family School of Philanthropy at Indiana University Purdue University Indianapolis. Her scholarship and research relates to community engagement in higher education and she has responsibilities for leading the research and scholarship of CSL. Julie is a member of the campus Community Engagement Leadership Team within the Office of Community Engagement. She also serves on the National Advisory Board for the Carnegie Classification for Community Engagement and was part of the rubric development team for AAC\&U Civic Engagement Rubric and the Civic Knowledge Rubric.

HEATHER PEASE (heather.pease@outlook. com) is currently a doctoral candidate in Research Methodology at Loyola University Chicago. Her dissertation topic is social scientists' conceptualization and implementation of research ethics and integrity. Heather is also a former student of Dan Richard. Their mentor-mentee relationship began as a result of a service-learning graduate course in quasi-experimental design in 2010. 